\title{
Preferensi Muzakki Membayar Zakat Melalui Baitul Mal: Studi Empiris di Kota Banda Aceh
}

\author{
Khairul Amri ${ }^{1}$, Marwiyati ${ }^{2}$ \\ Fakultas Ekonomi dan Bisnis Islam, Universitas Islam (UIN) Ar-Raniry, Banda Aceh ${ }^{2}$ \\ Correspondence email: khairul.amri@ar-raniry.ac.id
}

\begin{abstract}
This study aims to analyze the preferences of muzakki paying zakat in Baitul Mal Aceh and the differences in preferences based on socio-demographic characteristics. The study was conducted on 282 muzakki in the city of Banda Aceh. Data collection using a questionnaire and then the data were analyzed using descriptive statistics average method and inference statistics Mann-Whitney test method. The study found that the most determines of muzakki preference in paying zakat through Baitul Mal is the muzakki social environment, followed by Baitul Mal services quality, understanding of zakat management by the institution and the ease of reaching the Baitul Mal location. Mann-Whitney Test different test results indicate that muzakki preferences differ significantly by sex, occupation, and income per month, but not significantly based on age, marital status, and education level.
\end{abstract}

Keywords : Zakat, Muzakki Preference, Mann-Whitney Test

\section{PENDAHULUAN}

Pembayaran zakat merupakan suatu kewajiban, memiliki peraturan dan ketentuan yang telah ditetapkan, dan ditujukan kepada pihak-pihak tertentu yang memenuhi syarat. Dalam konsep Islam, pemerintah dapat melakukan suatu aturan yang mendorong untuk memberikan bantuan kepada kelompok yang membutuhkan berupa zakat yang berfungsi untuk memberikan bantan sosial bagi masyarakat. Atas dasar itu, berdirinya lembaga zakat seperti halnya Baitul Mal di Aceh merupakan salah satu langkah konkrit pemerintah daerah untuk melembagakan pengelolaan zakat. Melalui Baitul Mal diharapkan penerimaan dana zakat lebih mudah untuk dikelola, sehingga penyaluran zakat kepada masyarakat miskin lebih terkoordinir dengan baik. Hal ini diharapkan dapat memudahkan pemerintah daerah dalam mengoptimalkan penggunaan dana zakat untuk meningkatkan kesejahteraan masyarakat miskin. Penerimaan dana zakat oleh Baitul Mal tentunya tidak terlepas dari tingkat kesadaran masyarakat yang dalam hal ini adalah para muzakki untuk membayarkan zakat mereka melalui lembaga tersebut. Kenyataan menunjukkan bahwa tidak semua wajib zakat memanfaatkan Baitul Mal untuk membayar zakat.Sebagian di antara mereka justru lebih tertarik untuk menyalurkan zakat langsung ke para mustahik zakat yang mereka pilih. Bahkan juga ada di antara muzakki yang membayarkan zakat melalui lembaga perantara seperti halnya Rumah Zakat dan lembaga lainnya yang juga bergerak dalam bidang yang sama.

Adanya perbedaan perilaku muzakki dalam memilih saluran pembayaran zakat seperti dijelaskan di atas kiranya akan terus menjadi persoalan serius ketika pemerintah daerah menginginkan agar pengelolaan dana zakat dapat dilakukan secara lebih terarah. Sebab, penyaluran dana zakat kepada kelompok mustahik tertentu oleh baitul mal bisa saja tumpang tindih dengan penyaluran zakat oleh individu atau pun lembaga lain selain baitul mal. Karena itu, idealnya pembayaran dana zakat oleh muzakki dilakukan secara satu pintu yakni melalui Baitul Mal. Pemahaman perilaku muzakki dalam membayar zakat melalui Baitul Mal adalah sesuatu hal sangat penting bagi pemerintah daerah terutama lembaga pengelola zakat. Paling tidak dengan memahami perilaku masyarakat dalam membayar zakat dapat diperoleh informasi empiris sebagai dasar pertimbangan penting dalam menyusun kebijakan sosial zakat di masa yang akan datang. Dengan kata lain, Baitul Mal sebagai lembaga pengelola zakat harus mengambil kebijakan yang berorientasi pada peningkatan minat muzakki untuk membayar zakat melalui lembaga tersebut. Kebijakan dimaksud hanya akan dapat dilakukan ketika baitul memiliki bukti empiris tentang faktor-faktor pembentuk perilaku atau preferensi muzakki dalam memilih Baitul Mal Aceh dalam membayar zakat.

Hingga saat ini terdapat beberapa kajian yang berkaitan dengan perilaku muzakki membayar zakat. Idris et al. (2012) dalam kajian mereka tentang kepatuhan membayar zakat di Malaysia menemukan bahwa religiusitas atau tingkat pemahaman agama merupakan faktor penentu bagi kepatuhan muzakki membayar zakat. Selanjutnya Triyawan \& Aisyah (2016) dalam kajian mereka tentang perilaku muzakki membayar zakat di Baznas menyimpulkan bahwa kepercayaan, regulasi dan produk Baznas secara parsial dan simultan 
berpengaruh terhadap kepentingan muzakki membayar zakat di Baznas. Berbeda dengan kedua penelitian tersebut, penelitian ini mengkaji tentang preferensi muzakki membayar zakat melalui Baitul Mal Aceh.Hasil penelitian tidak hanya mengungkapkan model preferensi muzakki dalam membayar zakat, tetapi juga dapat memberikan bukti empiris tentang perbedaan preferensi muzakki berdasarkan sejumlah karakteristik sosial demografi seperti pendidikan, pekerjaan, pendapatan dan lain sebagainya.Sehingga temuan penelitian dapat berguna untuk pengambilan kebijakan oleh manajemen Baitul Mal sebagai pengelola zakat di Aceh.

\section{Kajian Teori dan Penelitian Terkait}

Minat membayar zakat dapat diartikan sebagai kesadaran membayar zakat sesuai dengan ketentuan syariat, seperti nishab, haul, serta cara mengeluarkannya secara benar (melalui amil) merupakan bentuk dan perwujudan kepatuhan muzakki terhadap perintah zakat (Bachmid, 2012). Bentuk dan perwujudan kepatuhan merupakan penggambaran dari perilaku muzakki dalam membayar zakat, yang banyak dipengaruhi oleh tingkat keyakinan, pemahaman, kecenderungan dan minat yang dimilki oleh muzakki. Keputusan muzakki dalam membayar zakat pada lembaga zakat seperti halnya Baitul Mal misalnya, terkait dengan beberapa faktor diantaranya religiusitas atau pemahaman agama (Idris et al., 2012); sikap dan norma subjektif (Alpriyamah dan Adityawarman, 2017); kepercayaan dan regulasi (Triyawan dan Aisyah, 2016); pengetahuan, sikap terhadap pentingnya zakat, religiusitas atau pemahaman agama, motivasi dan pendapatan (Sedjati et al., 2018). Preferensi dapat diartikan sebagai pilihan atau penilaian yang dibuat seseorang berdasarkan pemeringkatan terhadap produk dan jasa sebagai alternatif pilihan yang tersedia (Koo, Tao, \& Yeung, 1999). Preferensi seseorang dalam kaitannya dengan objek tertentu berkaitan dengan kecenderungannya memilih atau tidak memilih objek tersebut yang didasarkan pada sejumlah pertimbangan yang dibuatnya. Preferensi muzakki dalam menyalurkan dana zakat misalnya, sangat bervariasi, karena setiap muzakki memiliki keinginan dan pilihan yang berbeda-beda. Namun secara umum, tingkat preferensi muzakki tersebut dapat diperoleh berdasarkan faktor-faktor (internal dan eksternal) yang menjadi dasar pertimbangan pemilihan tempat penyaluran dana zakat. Kajian mengenai perilaku muzakki dalam membayar zakat telah dilakukan oleh peneliti-peneliti sebelumnya. Idris et al. (2012) dalam penelitian mereka mengenai kepatuhan membayar zakat di Malaysia menyimpulkan bahwa religiusitas merupakan determinan penting kepatuhan membayar zakat. Penelitian Triyawan dan Aisyah (2016) berkaitan dengan perilaku membayar zakat di Yogyakarta menemukan bahwa faktor-faktor yang mempengaruhi minat muzakki membayar zakat di Baznas Yogyakarta adalah kepercayaan terhadap lembaga tersebut serta regulasi terkait pembayaran zakat. Selanjutnya penelitian Alpriyamah dan Adityawarman (2017) menyajikan bukti empiris bahwa perilaku/kepatuhan muzakki dalam membayar zakat terkait dengan sikap, norma subjektif dan intensi berperilaku (behavioral intention). Penelitian terbaru yang mengkaji tentang perilaku muzakki membayar zakat dilakukan oleh Sedjati et al. (2018) di Jakarta yang menyimpulkan bahwa perilaku muzakki membayar zakat secara signifikan dipengaruhi oleh pengetahuan, sikap terhadap pentingnya zakat, religiusitas atau pemahaman agama, motivasi dan pendapatan muzakki.

\section{Kerangka Pemikiran}

Perilaku muzakki dalam membayar zakat tentunya terkait dengan beberapa faktor. Kendatipun zakat merupakan kewajiban bagi setiap muslim yang telah memenuhi syarat sebagai wajib zakat, namun dalam membayar zakat mereka dihadapi pada beberapa pilihan. Pilihan tersebut tidak hanya terkait dengan pilihan terhadap mustahik zakat, waktu pembayaran zakat dan lain sebagainya, tetapi lebih penting lagi pilihan mengenai penyaluran zakat tersebut (secara langsung ke mustahik yang diinginkan atau melalui lembaga pengelola zakat). Keputusan muzakki dalam memilih Baitul Mal sebagai tempat membayarkan dana zakat tentunya terkait berbagai faktor seperti kepercayaan terhadap lembaga tersebut, kemudahan menjangkau lokasi, pelayanan (kemudahan membayar), pemahaman terhadap pengelolaan zakat, pemahaman agama (religiusitas), informasi publik dan lingkungan muzakki itu sendiri. Lingkungan yang dimaksudkan dalam hal ini dapat berupa kelompok referensi bagi muzakki ketika mereka ingin membayarkan zakat. Keseluruhan faktor-faktor tersebut dapat dipandang sebagai preferensi bagi keputusan muzakki dalam memanfaatkan Baitul Mal sebagai tempat membayar zakat.

Perbedaan kepercayaan muzakki terhadap Baitul Mal sebagai lembaga pengelola zakat diperkirakan dapat berdampak pada perilaku mereka dalam membayar zakat pada lemaga tersebut. Demikian pula halnya 
dengan perbedaan persepsi muzakki terhadap kemudahan menjangkau lokasi dan kemudahan pelayanan Baitul Mal, perbedaan pemahaman tentang pengelolaan zakat, pemahaman agama, informasi publik dan lingkungan muzakki juga dapat menjadi determinan penting keputusan mereka membayar zakat pada lembaga pengelola zakat tersebut. Karakteristik seseorang mempengaruhi pembentukan preferensi karena memiliki cara dan kemampuan yang berbeda dalam membentuk persepsi. Informasi apa yang diinginkan, bagaimana menginter pretasikan informasi tersebut dan informasi apa yang diingat, tergantung dari karakteristik individu, seperti tingkat pendidikan, umur, jenis kelamin, keperibadian dan lain-lain (Simamora, 2004:188). Karakteristik sosial demografi muzakki terutama latar belakang pendidikan, pendapatan dan pekerjaan juga akan dapat menjadi pembeda pandangan mereka terhadap pentingnya membayar zakat melalui Baitul Mal.

\section{METODE}

Populasi penelitian adalah masyarakat muslim di Kota Banda Aceh yang sudah memiliki kewajiban membayar zakat. Sampel penelitian sebanyak 282 orang muzakki yang diambil secara random sampling. Mereka berasal dari berbagai latar belakang pendidikan dan pekerjaan. Preferensi muzakki dalam membayar zakat pada Baitul Mal yang meliputi kepercayaan pada Baitul Mal, lokasi Baitul Mal, pelayanan/kemudahan membayar, pemahaman terhadap pengelolaan zakat, pemahaman agama, informasi publik dan lingkungan muzakki. Selain itu, sesuai dengan tujuan penelitian, karakteristik sosial demografis yang meliputi jenis kelamin, usia, status perkawinan, tingkat pendidikan, pekerjaan dan pendapatan juga merupakan operasional variabel. Pengumpulan data dilakukan dengan mengedarkan kuesioner yang berisi pernyataan/pernyataan yang berhubungan dengan operasional variabel. Masing-masing pernyataan disediakan alternatif pilihan jawaban dalam bentuk tingkat kesetujuan yang diberikan skor menurut skala Likert 1-5. Penggunaan skala tersebut dalam memberikan skor atau bobot terhadap alternatif pilihan jawaban kuesioner penelitian yang bertujuan untuk mengukur persepsi atau penilaian terhadap suatu pernyataan telah umum dilakukan oleh sejumlah peneliti (Amri \& Surya, 2013; Amri et al., 2018). Muzakki diminta untuk memberikan respon terhadap masing-masing pernyataan terkait dengan memilih salah satu alternatif pilihan jawaban yang paling cocok. Selanjutnya peralatan analisis data yang digunakan dalam penelitian ini terdiri dari statistik deskriptif dan statistik infrensial.Statistik deskripsi yang digunakan adalah metode rata-rata. Selanjutnya statistik inferensi yang digunakan adalah uji beda metode Mann-Whitney (U-Test).

\section{HASIL}

Preferensi muzakki membayar zakat melalui Baitul Mal didekati dengan penilaian mereka terhadap tujuh faktor terdiri dari kepercayaan terhadap lembaga tersebut, kemudahan menjangkau lokasi, pelayanan, pemahaman terhadap pengelolaan zakat, pemahaman agama (religiusitas), informasi publik dan lingkungan muzakki. Berdasarkan hasil pengolahan data, diantara tujuh faktor tersebut, lingkungan muzakki merupakan preferensi yang sangat menentukan bila dibandingkan dengan indikator lain. Hal ini disebabkan nilai rerata skor tingkat kesetujuan responden terhadap tiga indikator yang berkaitan dengan faktor tersebut sebesar 4,021 lebih besar bila dibandingkan dengan 6 (enam) faktor lainnya. Dengan demikian berarti kecenderungan atau preferensi utama muzakki membayar zakat melalui Baitul Mal di kota Banda Aceh adalah faktor lingkungan muzakki itu sendiri. Pada umumnya keputusan mereka untuk membayar zakat melalui lembaga tersebut tidak terlepas dari informasi yang mereka peroleh dari lingkungan. Ketika keluarga atau pun rekan kerja mereka membayar zakat melalui lembaga tersebut, maka informasi tersebut juga dapat menimbulkan minat mereka untuk membayar zakat melalui Baitul Mal. Tabel 1 memperlihatkan nilai rerata skor tingkat kesetujuan muzakki terhadap pernyataan yang berhubungan dengan tujuh faktor penting sebagai tolok ukur preferensi mereka membayar zakat melalui Baitul Mal. 
Tabel 1.

Deskripsi Preferensi Muzakki Membayar Zakat Melalui Baitul Mal.

\begin{tabular}{llrl}
\hline & \multicolumn{1}{c}{ Preferensi Muzakki } & Nilai RerataSkor & \multicolumn{2}{c}{ Keterangan Preferensi } \\
\hline 1 & Kepercayaan & 3,865 & Preferensi utama yang menentukan \\
2 & Kemudahan menjangkau lokasi & 3,940 & diantara semua preferensi adalah \\
3 & Pelayanan & 3,947 & lingkungan muzakki, kemudian diikuti oleh \\
4 & Pemahaman terhadap pengelolaan zakat & 3,940 & pelayanan Baitul Mal, pemahaman \\
5 & Pemahaman agama (religiusitas) & 3,922 & terhadap pengelolaan zakat oleh lembaga \\
6 & Informasi publik & 3,897 & tersebut serta kemudahan menjangkau \\
7 & Lingkungan muzakki & 4,021 & lokasi Baitul Mal. \\
\hline
\end{tabular}

Sumber: Data Olahan

Setelah faktor lingkungan muzakki sebagai preferensi utama dalam membayar zakat melalui Baitul Mal, faktor berikutnya adalah pelayanan lembaga tersebut dengan nilai rata-rata skor sebesar 3,947. Kemudian menyusul kemudahan menjangkau lokasi/kantor baitul mal dan pemahaman muzakki tentang pengelolaan zakat oleh lembaga tersebut diurutan kedua dan ketiga dengan nilai rata-rata skor masingmasing sebesar 3,940. Selanjutnya pemahaman agama dan informasi publik berada pada urutan kelima dan keenam dengan nilai rata-rata skor masing-masing sebesar 3,922 dan 3,897. Pengujian apakah preferensi muzakki laki-laki berbeda dengan preferensi muzakki perempuan dalam membayar zakat melalui Baitul Mal menunjukkan nilai Z hitung sebesar -2,141.Pengujian dilakukan untuk dua sisi yang berarti adalah sisi kiri dan sisi kanan sehingga (dalam hal ini nilai negatif diabaikan karena pengujian dilakukan dua sisi). Nilai kritis $\mathrm{Z}$ untuk tes dua sisi pada signifikansi 5\% atau tingkat keyakinan sebesar 95 persen menunjukkan angka sebesar 1,96. Karena nilai $Z$ hitung $>Z$ tabel $(-2,141>1,96)$ maka dapat diartikan bahwa preferensi kedua kelompok muzakki (laki-laki dan perempuan) berbeda secara signifikan. Dengan kata lain, perbedaan jenis kelamin menyebabkan adanya perbedaan preferensi dalam memilih baitul mal sebagai tempat membayar zakat.

Selanjutnya untuk karakteristik umur, muzakki hanya dikelompokkan dalam dua kelompok umur yaitu dibawah 35 tahun dan di atas 35 tahun.Hal ini disebabkan uji Mann-Whitney Test hanya bisa digunakan untuk membedakan dua jenis kelompok data. Hasil pengujian menunjukkan nilai $\mathrm{Z}$ hitung sebesar -0,464 lebih kecil bila dibandingkan dengan nilai kritis $\mathrm{Z}$ untuk tes dua sisi pada signifikansi $5 \%$ atau tingkat keyakinan sebesar 95 persen $(-0,464<1,96)$ juga dapat diartikan bahwa preferensi muzakki dengan usia di atas 35 tahun tidak berbeda signifikan dengan preferensi muzakki dengan usia dibawah 35 tahun. Artinya preferensi muzakki membayar zakat melalui baitul mal di kota Banda Aceh tidak berbeda antara mereka dengan usia di atas 35 tahun dengan mereka dengan usia dibawah 35 tahun.

Selanjutnya uji beda apakah perbedaan status perkawinan dapat menyebabkan perbedaan preferensi muzakki menunjukkan nilai $\mathrm{Z}$ hitung sebesar -0,936. Angka ini juga lebih kecil bila dibandingkan dengan harga kritis $\mathrm{Z}$ untuk tes dua sisi pada signifikansi 5\% atau tingkat keyakinan sebesar 95 persen sebesar 1,96 $(-0,936<1,96)$. Dengan demikian dapat diartikan bahwa perbedaan status perkawinan tidak menimbulkan perbedaan preferensi preferensi muzakki. Dengan kata lain, preferensi muzakki membayar zakat melalui Baitul Mal tidak berbeda signifikan antara mereka yang sudah dan belum menikah. Karakteristik responden selanjutnya tingkat pendidikan.Dalam hal ini muzakki hanya dikelompokkan dalam 2 kelompok tingkat pendidikan, yaitu mereka dengan latar belakang pendidikan perguruan tinggi dan mereka dengan latar belakang pendidikan bukan perguruan tinggi. Hasil pengujian uji beda rata-rata dengan peralatan statistik Mann-Whitney Test menunjukkan nilai $Z$ hitung sebesar -1,163. Angka ini lebih kecil dari kritis $Z$ untuk tes dua sisi pada signifikansi 5\%, sehingga dapat diartikan bahwa tidak terdapat perbedaan preferensi antara muzakki yang memiliki latar belakang perguruan tinggi dengan muzakki yang berasal dari latar belakang pendidikan bukan perguruan tinggi. Untuk lebih jelasnya mengenai hasil pengujian uji beda rata-rata preferensi muzakki dalam membayar zakat melalui Baitul Mal di kota Banda Aceh berdasarkan karakteristik sosial demografis dapat dilihat Tabel 2. 
Tabel 2.

Hasil Uji Beda Rata-rata preferensi Muzakki Membayar Zakat Melalui Baitul Mal Berdasarkan Karakteristik Sosial Demografi

\begin{tabular}{|c|c|c|c|c|}
\hline $\begin{array}{l}\text { Karakteristik Sosial } \\
\text { Demografi }\end{array}$ & $\begin{array}{l}\text { Nilai } \\
\text { Z hitung }\end{array}$ & Sig & $\begin{array}{l}\text { Harga Kritis } \\
\mathrm{Z}(\mathrm{Z} \text { tabel })\end{array}$ & Keterangan \\
\hline $\begin{array}{ll}\text { Jenis } & \text { Kelamin } \\
-\quad & \text { Laki-laki } \\
- & \text { Perempuan }\end{array}$ & $-2,141$ & 0,032 & 1,960 & Berbedasignifikan \\
\hline $\begin{array}{ll}\text { Usia } & \\
-\quad & <35 \text { tahun } \\
-\quad>35 \text { tahun }\end{array}$ & $-0,464$ & 0,643 & 1,960 & $\begin{array}{r}\text { Tidak berbeda } \\
\text { signifikan }\end{array}$ \\
\hline $\begin{array}{l}\text { Status Perkawinan } \\
-\quad \text { Menikah } \\
-\quad \text { Belum menikah }\end{array}$ & $-0,936$ & 0,349 & 1,960 & $\begin{array}{r}\text { Tidak berbeda } \\
\text { signifikan }\end{array}$ \\
\hline $\begin{array}{l}\text { Tingkat Pendidikan } \\
-\quad \text { Perguruan tinggi } \\
-\quad \text { Bukan perguruan tinggi }\end{array}$ & $-1,163$ & 0,245 & 1,960 & $\begin{array}{r}\text { Tidak berbeda } \\
\text { signifikan }\end{array}$ \\
\hline $\begin{array}{l}\text { Pekerjaan } \\
\text { - } \quad \text { Wirausahawan/Pengusaha } \\
-\quad \text { Bukan Wirausahawan/ Pengusaha }\end{array}$ & $-3,769$ & 0,000 & 1,960 & Berbeda signifikan \\
\hline $\begin{array}{l}\text { Pendapatan rata-rata perbulan } \\
-\quad<\operatorname{Rp~} 5.000 .000 \\
-\quad>\operatorname{Rp} 5.000 .000\end{array}$ & $-4,197$ & 0,000 & 1,960 & Berbeda signifikan \\
\hline
\end{tabular}

Sumber: Data olahan

Selanjutnya dalam pengujian statistik muzakki dibedakan dalam dua kelompok pekerjaan yaitu pengusaha/wiraswastawan dan bukan pengusaha/wiraswastawan.Hasil pengujian menunjukkan nilai $\mathrm{Z}$ hitung sebesar -3,769 (dalam hal ini nilai negatif diabaikan karena pengujian dilakukan dua sisi). Angka ini lebih besar bila dibandingkan dengan nilai $\mathrm{Z}$ tabel sebesar 1,960.Dengan demikian dapat diartikan terdapat perbedaan preferensi muzakki membayar zakat melalui Baitul Mal berdasarkan jenis pekerjaan yang ditekuni. Dengan kata lain, muzakki dengan pekerjaan sebagai pengusaha/wiraswasta memiliki preferensi yang berbeda dalam membayar zakat pada lembaga tersebut bila dibandingkan dengan muzakki dengan pekerjaan bukan pengusaha/wiraswasta. Berdasarkan Tabel 2 di atas juga dapat dilihat bahwa preferensi muzakat dalam membayar zakat melalui Baitul Mal di kota Banda Aceh uga berbeda pendapatan rata-rata per bulan. Preferensi muzakki yang memiliki pendapatan rata-rata relatif besar yaitu di atas dan dibawah $\mathrm{Rp}$ 5.000.000 per bulan menyalurkan zakat melalui lembaga tersebut berbeda signifikan dengan preferensi muzakki dengan pendapatan rata-rata di bawah Rp5.000.000 per bulan.

\section{SIMPULAN}

Mengacu pada hasil penelitian dapat disimpulkan bahwa preferensi muzakki membayar zakat melalui Baitul Mal di kota Banda Aceh relatif berbeda satu sama lain. Preferensi yang paling dominan mendorong mereka membayar zakat melalui lembaga tersebut lingkungan muzakki itu sendiri, kemudian diikuti oleh pelayanan Baitul Mal, pemahaman terhadap pengelolaan zakat oleh Baitul Mal persepsi mereka tentang kemudahan menjangkau lokasi Baitul Mal. Hasil pengujian statistik menyimpulkan bahwa preferensi muzakki berbeda signifikan berdasarkan jenis kelamin, pekerjaan dan pendapatan per bulan, tetapi tidak signifikan berdasarkan tingkatan usia, status perkawinan dan dan tingkat pendidikan. Berdasarkan kesimpulan tersebut, maka rekomendasi utama penelitian ini adalah Baitul Mal sebagai lembaga pengelola zakat di Kota Banda Aceh dipandang perlu meningkatkan intensitas sosialisasi lembaga tersebut kepada seluruh lapisan masyarakat. Upaya sosialisasi sebaiknya juga seiring dengan upaya peningkatan pemahaman masyarakat tentang pengelolaan zakat oleh lembaga tersebut.

\section{DAFTAR PUSTAKA}

Amri, K., \& Surya, J. 2013. Kajian Perilaku Mahasiswa Dalam Menggunakan Internet Dengan Pendekatan Technology Acceptance Model (TAM), Jurnal Penelitian Pos dan Informatika 3 (1), 67-80.

Amri, K., Qurratul'aini, I., \& Julianty. 2018. Preferensi Nasabah Memilih Produk Pembiayaan Bank Aceh Syariah di Kota Banda Aceh, Jurnal Samudra Ekonomi dan Bisnis 9(1), 31-41. 
Alpriyamah, Q. U., \& Adityawarman, 2017.Analisis Faktor-Faktor Yang Mempengaruhi Perilaku Kepatuhan (Compliance Behavior) Pembayaran Zakat Perdagangan (Studi Kasus Pengusaha Muslim Batik di Kota Pekalongan Tahun 2017), Diponegoro Journal of Accounting, (6)3, 1-13.

Bachmid, G. 2012 Perilaku Muzakki dalam Membayar Zakat Mal (Studi Fenomenologi Pengalaman Muzakki Kota Kendari, Jurnal Aplikasi Manajemen, 10(2),425-436.

Idris, K. M., Bidin, Z., \& Saad, R. A. J. 2012. Islamic Religiosity Measurement and Its Relationship with Business Income Zakat Compliance Behavior, Jurnal Pengurusan 34, 3 - 10.

Koo, L.C., Tao, F. K. C., \& Yeung, J. H. C. 1999. Preferential Segmentation of Restaurant Attributes through Conjoint Analysis. International Journal of Contemporary Hospitality Management, 11/5: 242-250.

Sedjati, D. P., Basri, Y. Z., \& Hasanah, U. 2018. Analysis of Factors Affecting the Payment of Zakat in Special Capital Region (DKI) of Jakarta, International Journal of Islamic Business \& Management, 2(1), 24-34.

Simamora, B. 2004. Panduan Riset Perilaku Konsumen, Gramedia Pustaka Utama, Jakarta.

Triyawan, A., \& Aisyah, S. 2016. Analisis Faktor-Faktor Yang Mempengaruhi Muzakki Membayar Zakat di BAZNAS Yogyakarta, Islamic Economics Journal, 2(1), 53-69. 